\title{
GRAIN YIELD OF DIFFERENT SOYBEAN GENOTYPES CULTIVATED IN LOWLAND SOILS IN THREE SOWING TIMES
}

\author{
Thiago Assunção Almeida', Paulo Roberto Fidelis Giancotti', Bento Alvenir Dornelles de Lima', Douglas \\ Dalla Nora', Rafael Goulart ${ }^{1}$
}

${ }^{1}$ Instituto Federal Farroupilha (IFFar) Campus Alegrete. RS 377, Km 27, CEP: 97555-000, Alegrete - RS, Brazil. Tel: 55-55-9-9956-1992.

Autor para correspondência: Thiago Assunção Almeida, thiago.almeida@iffarroupilha.edu.br

\begin{abstract}
Soybean (Glycine max L. Merril) has been cultivated in regions of lowland soils in crop rotation with irrigated rice in order to reduce the infestation of red rice and due to the attractive soybean value in the world market. Soybean cultivation under this condition is subject to possible soil flooding, requiring recommendations of genotypes adapted to this environment. The aim of this study was to evaluate the grain yield of soybean genotypes grown in floodplain environment at three different sowing times. Cultivars used were A6411 RG, A7321 RG, BMXApolo RR, BMX Ativa RR, BMX Energia RR, BMX Potência RR, BMX Turbo RR, IGRA RA 518 RR, IGRA RA 626 RR, IGRA RA 628 RR, NA 5909 RG , NS 6262 RR, NS 7100 RR, RA 728 RR and VMax RR; sown in October, November and December. The experimental design was 15 (cultivars) $\times 3$ (times) factorial with 4 replicates. Significant differences were observed for sowing times and cultivars, as well as for the interaction between the two factors. Cultivars sown in November and December provided higher yields than those sown in October. BMX Turbo RR cultivar showed higher consistency for soybean yield in lowland, considering the sowing times evaluated. For early sowing (October and November), A6411 RG cultivar presented higher grain yield compared to the other cultivars.
\end{abstract}

KEYWORDS: Glycine max, lowland, cultivar, sowing times.

\section{RENDIMENTO DE GRÃOS DE GENÓTIPOS DE SOJA EM VÁRZEA CULTIVADOS EM TRÊS ÉPOCAS DE SEMEADURA}

RESUMO: A cultura da soja (Glycine max L. Merril) vem sendo cultivada em regiões de solos de várzea em rotação de cultura com arroz irrigado buscando diminuição da infestação de arroz vermelho e pelo valor atrativo da commodity no mercado mundial. 0 cultivo da soja nessa condição está sujeito a eventuais condições de alagamento do solo, carecendo de recomendações de genótipos adaptados a este ambiente. 0 objetivo deste trabalho foi avaliar o rendimento de grãos de diferentes genótipos de soja cultivados em ambiente de várzea em três épocas de semeadura. Os cultivares utilizados foram A 6411 RG, A 7321 RG, BMX Apolo RR, BMX Ativa RR, BMX Energia RR, BMX Potência RR, BMX Turbo RR, IGRA RA 518 RR, IGRA RA 626 RR, IGRA RA 628 RR, NA 5909 RG, NS 6262 RR, NS 7100 RR, RA 728 RR e VMax RR; semeadas em outubro, novembro e dezembro. 0 delineamento experimental foi em esquema fatorial de 15 (cultivares) $\times 3$ (épocas) com 4 repetições. Observou-se diferenças significativas para época e cultivar, além de interação entre os dois fatores. Cultivares de soja semeadas em novembro e dezembro proporcionaram rendimento de grãos superiores às semeadas em outubro. 0 cultivar BMX Turbo RR apresentou maior consistência para rendimento de grãos na área de várzea considerando todas as épocas de semeadura avaliadas. Para a semeadura precoce (outubro e novembro), o cultivar A 6411 RG apresentou rendimento de grãos superior, quando comparado aos outros cultivares.

PALAVRAS CHAVES: Glycine max, várzea, cultivar, época de plantio.

\section{INTRODUCTION}

In lowland soils, soybean cultivation [Glycine $\max ($ L.) Merril.], in rotation with irrigated rice [Oryza sativa L.], is an important tool for the success of the rice activity, since it increases nutrient cycling and nitrogen incorporation, improves soil physical structure and reduces the risk of resistance of red rice to ALS inhibitor herbicides (imidazolinones) through the use of herbicides with other mechanisms of action. This practice also promotes pest and disease control, 
reduces soil preparation cost in irrigated rice cultivation and increases rice yield (Vernetti Junior et al., 2003; Vernetti Junior et al., 2009).

Alternatives for the management of soils cultivated with irrigated rice that are, at the same time, more efficient in the control of red rice, economically viable and able to provide more rational use of soil have been sought (Gomes et al., 1992). Among management methods, crop rotation stands out in the efficiency of red rice control (Marchezan et al., 1995; Avila, 1999). However, there is great difficulty in adopting the cultivation of another grain crop in hydromorphic soils due to issues of adaptability to this condition. Pires et al. (2002) point out that soybean can be considered a viable alternative in this system, since some cultivars have mechanisms of adaptation to flooded soils.

Problems related to the low hydraulic conductivity of soils are frequent in periods of high rainfall, not only in floodplain soils with low drainage capacity. Under these conditions, crop performance is affected, as flooding modifies the soil atmosphere, promoting $\mathrm{O}_{2}$ deficiency, $\mathrm{CO}_{2}$, methane, ethylene, sulphydric gas $\left(\mathrm{H}_{2} \mathrm{~S}\right)$ accumulation and reducing aerobic respiration (Pires et al., 2002).

According to Taiz and Zeiger (2009), in sensitive plants, conditions of flooded soil alter plant metabolism, reducing the productivity of unadapted crops. The extent of the damage caused by flooded soils depends on several factors such as duration of the flood period, development stage of the plant in which it occurs, species and / or cultivar, and environmental conditions such as temperature and soil carbon dioxide content. Soil water saturation, applied to leguminous, impairs the development of roots and shoots and also the nitrogen fixation by the root system due to the reduction of oxygen to nodules, resulting in a consequent reduction in the number of nodules per root area (Barni and Costa, 1975; De Wit, 1978). For the soybean crop, soil water saturation during the vegetative stage slows the vegetative development and reduces the number of flowers as well as grain yield.

Genetic diversity can provide different responses of plants to flooding, including changes in architecture, metabolism, and biomass accumulation (Serres and Voesenek, 2008). There is great difficulty for farmers to choose soybean genotypes adapted to cultivation in hydromorphic soil. Thus, studies that describe the behavior of these cultivars to provide farmers the best choice are needed. The aim of this study was to evaluate the grain yield of different soybean genotypes grown in a floodplain environment at three sowing times.

\section{MATERIAL AND METHODS}

The experiment was conducted in the 2011/12 crop season at the "Agropecuária Nemitz" experimental area located at the "Fronteira Oeste" region, municipality of Manoel Viana, RS, Brazil, with the following coordinates $29^{\circ} 39$ ' 19.87 "S and $55^{\circ} 25$ ' $55.44^{\prime \prime}$ and altitude of $79 \mathrm{~m}$ a.s.l., According to the Köeppen classification (Moreno, 1961), the climate is Cfa type (humid subtropical), without dry season and temperatures ranging from $14.3^{\circ} \mathrm{C}$ in the winter to $26.3^{\circ} \mathrm{C}$ in the summer, and average rainfall of $1400 \mathrm{~mm}$.

Chemical and physical analysis of the upper soil layer $(0-20 \mathrm{~cm})$ was carried out, identifying its sandy texture and the following chemical characteristics: $\mathrm{pH}$ 5.2 (water 1: 1), $8.00 \mathrm{mg} \mathrm{dm}^{-3}$ of P-Mehlich, 0.14, 0.5 and $1.5 \mathrm{cmol}_{\mathrm{c}} \mathrm{dm}^{-3}$ of $\mathrm{K} ; \mathrm{Mg}$; and $\mathrm{Ca}$, respectively. Fertilization of the experimental area was performed in accordance with the Manual of Fertilization and Liming for the States of Rio Grande do Sul and Santa Catarina (Brazilian Society of Soil Science, 2004) for soybean crop. According to the Brazilian Soil Classification System, the soil in the area was classified as Planosol (Embrapa, 2006).

Experimental units were arranged in a $15 \mathrm{x}$ 3 factorial scheme (fifteen cultivars and three sowing seasons), with four replicates. Soybean cultivars were A 6411 RG, A 7321 RG, BMX Apolo RR, BMX Ativa RR, BMX Energia RR, BMX Potência RR, BMX Turbo RR, IGRA RA 518 RR, IGRA RA 626 RR, IGRA RA 628 RR, NA 5909 RG, NS 6262 RR, NS 7100 RR, RA 728 RR and VMax RR, cultivated in October (10/13/2011), November (11/16/2011) and December (12/15/2011).

The experimental area used in the experiment was $200 \mathrm{~m}^{2}$ and each plot consisted of four rows of five meters in length, making up an area of $10 \mathrm{~m}^{2}$ per plot. For no tillage, the same seed density was used for all soybean varieties, 330,000 seeds ha $^{-1}$, with spacing between rows of $0.50 \mathrm{~m}$. Crop emergence occurred seven days after sowing. Plots were harvested according to the maturation group of the cultivar, as described in Table 1. 
Table 1. Harvest dates of soybean cultivars of similar maturation groups and days between sowing and harvest. Manoel Viana, 2011-2012.

\begin{tabular}{l|l|r}
\hline \multicolumn{1}{c|}{ Cultivars } & \multicolumn{1}{c}{ Harvest dates } & Days between sowing and harvest \\
\hline BMX Apolo RR & Sown in October: 03/17/2012 & 156 \\
BMX Ativa RR & Sown in November: 03/29/2012 & 134 \\
BMX Energia RR & Sown in December: 04/07/2012 & 114 \\
BMX Turbo RR & & \\
IGRA RA 518 RR & & \\
NA 5909 RG & & \\
VMax RR & & Harvest dates \\
\hline \multicolumn{1}{c|}{ Cultivars } & \multicolumn{1}{|c}{ Days between sowing and harvest } \\
\hline A6411 RG & Sown in October: 03/20/2012 & 159 \\
A 7321 RG & Sown in November: 03/31/2012 & 136 \\
BMX Potência RR & Sown in December: 04/09/2012 & 116 \\
IGRA RA 626 RR & & \\
IGRA RA 628 RR & & \\
NS 6262 RR & & \\
NS 7100 RR & & \\
\hline RA 728 RR & & \\
\hline
\end{tabular}

At the end of the experiment, grain yield was evaluated. For this, two rows of three central meters of the plot were collected. Plants were then manually trod. Cleaned grains were weighed and had moisture content determined for each plot. Then, weight was corrected to $13 \%$ moisture to obtain yield values in $\mathrm{kg} \mathrm{ha}^{-1}$.

Data were submitted to analysis of variance and averages compared by the Tukey's test at $5 \%$ error probability, using the SISVAR 4.3 statistical package (Ferreira, 2000).

\section{RESULTS}

The results of the analysis of variance are presented in Table 2, where interaction between factors cultivar and sowing season is observed, in addition to significant difference between cultivars and sowing times. Considering the average of the three periods evaluated, BMX Turbo RR cultivar presented the highest yield, with average of $5140 \mathrm{~kg} \mathrm{ha}^{-1}$, differing from BMX Ativa RR, which presented average of $2669 \mathrm{~kg} \mathrm{ha}^{-1}$, while the other cultivars evaluated did not differ from each other.

Table 2. Analysis of variance and comparison of yield means of soybean cultivars (kg ha-1) at different sowing times. Manoel Viana, 2011-2012.

\begin{tabular}{lc}
\hline Sowing time & Soybean grain yield $\left(\mathbf{k g ~ h a}^{-1}\right)$ \\
\hline October & $29655 \mathrm{~b}^{1}$ \\
November & $4071 \mathrm{a}$ \\
December & $4152 \mathrm{a}$ \\
\hline Cultivars & Soybean grain yield $\left(\mathbf{k g ~ h a}^{-1}\right)$ \\
\hline A 6411 RG & $4269 \mathrm{ab}$ \\
A 7321 RG & $3479 \mathrm{ab}$ \\
BMX Apolo RR & $3478 \mathrm{ab}$ \\
BMX Ativa RR & $2669 \mathrm{~b}$ \\
BMX Energia RR & $3897 \mathrm{ab}$ \\
BMX Potência RR & $3260 \mathrm{ab}$ \\
BMX Turbo RR & $5140 \mathrm{a}$ \\
IGRA RA 518 RR & $3845 \mathrm{ab}$ \\
IGRA RA 626 RR & $3243 \mathrm{ab}$ \\
IGRA RA 628 RR & $3773 \mathrm{ab}$ \\
NA 5909 RG & $4568 \mathrm{ab}$ \\
NS 6262 RR & $3017 \mathrm{ab}$ \\
NS 7100 RR & $3550 \mathrm{ab}$ \\
RA 728 RR & $4108 \mathrm{ab}$ \\
VMax RR & $3647 \mathrm{ab}$ \\
\hline VC $\%$ & \\
F time & \\
F cultivars & $10.16^{* *}$ \\
F time x cultivars & \\
\hline${ }^{1}$ Means followed by the same lowercase letter do not differ by the Tukey test at 5\% error probability. ${ }^{*} 5 \%$ probability of error. ${ }^{* *} 1 \%$ \\
probability of error.
\end{tabular}


Table 1 shows that cultivars of similar maturation groups presented a cycle advance according to the sowing delay. However, it can be seen in Table 2 that late sowing was beneficial for soybean production in the floodplain region, since sowing in November and December provided the best yields, differing from yield when sowing was carried out in October.

The comparison of grain yield means obtained by cultivars at each sowing time is presented in Table 3. When sowing was performed in October, A 6411 RG and NS 7100 RR cultivars showed the highest grain yield values (4719 and $4425 \mathrm{~kg} \mathrm{ha}^{-1}$, respectively), differing from BMX Apolo RR, BMX Potência RR, NS
6262 RR and BMX Ativa RR cultivars. BMX Ativa RR cultivar presented the lowest grain yield when sown in October, differing from all other cultivars. For the month of November, A 6411 RG cultivar also obtained better performance (4966 kg ha-1), similar to BMX Turbo RR (5379 kg ha-1), NA 5909 RG and RA 728 R, which differed from IGRA RA 626 RR and NS 7100 RR cultivars. When sowing occurred in December, BMX Turbo RR cultivar again stood out with the highest grain yield $\left(6612 \mathrm{~kg} \mathrm{ha}^{-1}\right)$, significantly exceeding the yield obtained by BMX Ativa RR, NS 7100 RR and A 6411 $R G$ cultivars; the other cultivars did not differ from each other for that sowing time.

Table 3. Yield of soybean cultivars ( $\left.\mathrm{kg} \mathrm{ha}^{-1}\right)$ at different sowing times. Manoel Viana, 2011-2012.

\begin{tabular}{|c|c|c|c|}
\hline \multirow[b]{2}{*}{ Cultivars } & \multicolumn{3}{|c|}{ Soybean grain yield $\left(\mathrm{kg} \mathrm{ha}^{-1}\right)$} \\
\hline & October & November & December \\
\hline A 6411 RG & $4719 \mathrm{Aa}^{1}$ & $4966 \mathrm{Aa}$ & $3121 \mathrm{~B} \mathrm{~b}$ \\
\hline A 7321 RG & 2629 A ab & $3985 \mathrm{Aab}$ & $3823 \mathrm{~A} a b$ \\
\hline BMX Apolo RR & $2040 \mathrm{~B} \mathrm{~b}^{*}$ & $3948 \mathrm{Aab}$ & $4447 \mathrm{~A} a b$ \\
\hline BMX Ativa RR & $1101 \mathrm{~B} \mathrm{C}$ & $3523 \mathrm{~A} a b$ & $3381 \mathrm{Ab}$ \\
\hline BMX Energia RR & $2888 B$ B ab & $4528 \mathrm{Aab}$ & $4276 \mathrm{~A} a b$ \\
\hline BMX Potência RR & 2146 B b & $3378 \mathrm{~A} a b$ & $4255 \mathrm{~A} a b$ \\
\hline BMX Turbo RR & $3428 \mathrm{~B}$ ab & $5379 \mathrm{Aa}$ & $6612 \mathrm{Aa}$ \\
\hline IGRA RA 518 RR & $2975 \mathrm{~B}$ ab & $4241 \mathrm{Aab}$ & 4319 A ab \\
\hline IGRA RA 626 RR & $2690 \mathrm{~B}$ ab & $2725 \mathrm{AB} \mathrm{b}$ & $4315 \mathrm{Aab}$ \\
\hline IGRA RA 628 RR & $3031 \mathrm{~A} a b$ & $4136 \mathrm{Aab}$ & $4151 \mathrm{~A} a b$ \\
\hline NA 5909 RG & 3872 A ab & $4835 \mathrm{Aa}$ & $4996 \mathrm{~A} a b$ \\
\hline NS 6262 RR & $2165 \mathrm{Ab}$ & $3226 \mathrm{~A} a b$ & $3658 \mathrm{Aab}$ \\
\hline NS 7100 RR & $4425 \mathrm{Aa}$ & $3009 \mathrm{Ab}$ & $3217 \mathrm{Ab}$ \\
\hline RA 728 RR & $2489 \mathrm{~B}$ ab & $5802 \mathrm{Aa}$ & $4032 A B$ ab \\
\hline VMax RR & $3877 \mathrm{Aab}$ & $3389 \mathrm{Aab}$ & $3677 \mathrm{Aab}$ \\
\hline
\end{tabular}

${ }^{1}$ Means followed by the same letter, lowercase in the column and upper case in the row, do not differ from each other by the Tukey test at $5 \%$ error probability.

\section{DISCUSSION}

Evaluating the interaction between water availability and critical development periods, Cunha et al. (2001) proposed the definition of a calendar for soybean cultivation in the Rio Grande do Sul state between October 11 and December 31, varying according to soil type and genetics of the cultivar. In the present experiment, the best performance of cultivars in the months of November and December, in detriment of the month of October (Table 2) can be explained by the higher luminosity and temperature conditions during the summer in the region, important characteristics for the good plant development and satisfactory yield (Sediyama et al., 2015).

The sowing scheduling is of great importance as a strategy to escape water deficiency, and can avoid periods of low rainfall during critical stages of development, such as flowering and vegetable fixation
(Mota, 1983). Observing the performance of cultivars within the sowing periods evaluated, cultivars with the greatest productive potential for each sowing period could be identified (Table 3). In general, the results are robust to support the assertion that $A 6411 R G$ and $B M X$ Turbo RR cultivars present good potential for early and later sowing, respectively. These results can be used in rural extension to confirm the ability of these cultivars for sowing at different times, whether for sowing scheduling, rationalization of equipment and labor, or other specific reason of each farm.

The poor performance of BMX Ativa RR cultivar was expected, since it is not indicated for the Western Frontier region of the state, being indicated for high- technology farming and areas of high soil fertility, according to the manufacturer. In addition, it is not recommended for sowing outside the month of November (Sementes Roos, 2018). 
Considering all sowing times, the cultivar that obtained the best grain yield performance was BMX Turbo RR. This cultivar is indicated for sowing in macro regions 1 and 2, including states of RS, SC, PR, SP, MS, in addition to Paraguay. It also shows lodging resistance, high level of branch formation and good rusticity, being moderately resistant to gall nematode, phytophthora root rot, among other diseases (Peron Ferrari, 2018). Such commercial characteristics of the material were positive for good crop performance in adverse conditions, such as the floodplain area of the present experiment. This result corroborate those of Reyna et al. (2003) and Missio et al. (2010), who also selected genotypes more tolerant to excess water.

The tolerance of soybean to waterlogging was investigated by Costa (1973), who submitted plants to soil with water saturation for a period of 4 months, when these plants remained alive, completed the cycle and produced grains. The evaluation of the diversity of cultivars tolerant to waterlogging conditions exposes plasticity in the metabolism, development and acclimatization of genotypes. Studies have allowed observing different adaptation strategies of plants to these environmental conditions, including detecting traces of tolerance (Serres and Voesenek, 2008). This result corroborates the present study, which showed that several soybean cultivars presented satisfactory yield, and some cultivars presented yields higher than $5 \mathrm{t} \mathrm{ha}^{-1}$ (Table 3 ).

According to Cunha et al. (2001), the southwestern region of the state, where soils have lower water retention capacity, is the most susceptible to loss of yield due to water deficiency. However, in the present experiment, conducted in this region, the average grain yield of soybean cultivars was relatively high (3729 $\mathrm{kg} \mathrm{ha}^{-1}$ ), exceeding the value found in an experiment also conducted in the central region of Rio Grande do Sul during the 2005/2006 crop season (3434 kg ha-1) by Missio et al. (2010). It is noteworthy that the grain yield found in the present experiment was also higher than the state average (1555 kg ha-1) in the same crop season (2011/2012), according to CONAB (2013). In that year, there were losses in practically all crops in the State of Rio Grande do Sul, mainly with soybean crop, which despite a $2.8 \%$ increase in planted area, recorded a $43.8 \%$ decrease in production mainly caused by the long dry season (G1 RS, 2012). This satisfactory yield in lowland area, considering the adverse conditions, is significantly useful for the elaboration of strategies related to the development of technologies of soybean production in these areas. Heatherly and Pringle (1991) identified that flood irrigation provided an increase in soybean yield in cultivars used in the alluvial plain of the southern Mississippi River, USA, when in water deficit during its reproductive phase. However, it is known that the excess of soil moisture content impairs the emergence of seedlings and negatively affects vigor and soybean seedlings (Gazolla-Neto et al., 2012).

Thus, it could be concluded that soybean cultivars sown in November and December provide grain yield higher than those sown in October in the experiment conducted in a floodplain area, and BMX Turbo RR cultivar presented greater consistency for grain yield in the floodplain area considering all the sowing times evaluated. For early sowing (October and November), A 6411 RG cultivar presented higher grain yield when compared to the other cultivars.

\section{REFERENCE}

Avila, L.A. Evolução do banco de sementes e controle do arroz vermelho (Oryza sativa L.) em diferentes sistemas de manejo do solo de várzea. Santa Maria: UFSM, 1999, 89 p. Dissertação (Mestrado em Agronomia) - Programa de pós-gradução em Agronomia, Universidade Federal de Santa Maria, 1999.

Barni, N.A.; Costa, J.A. Efeito de períodos de inundação do solo sobre o rendimento de grãos de soja (Glycine $\max (\mathrm{L})$ Merril). Agronomia Sulriograndense, 1975. 11, 2, 207-222.

CONAB - Companhia Nacional de Abastecimento. Acompanhamento da Safra Brasileira - Grãos Safra 2012/2013 Quinto Levantamento Fevereiro/2013. 2013. Disponivel em: <https://www.conab.gov.br/info-agro/ safras/graos/boletim-da-safra-de-graos?start=70>. Acesso em:4 jan 2019.

Costa, J.A. Efeito de inundação sobre a soja Glycine $\max (\mathrm{L})$ Merril. Agronomia Sulriograndense, 1973, 9, 1, 113-119.

Cunha, G.R. et al. Zoneamento agrícola e época de semeadura para soja no Rio Grande do Sul. Revista Brasileira de Agrometeorologia, 2001, 9, 3, 446-459. 
DeWit, M.C. Metabolic adaptation to anoxia. In: Hook, D.D. Crawford, E.M.M. Plant life in anaerobic environments. Michigan: Ann Arbor Science, 1978, 333-350.

Embrapa. Centro Nacional de Pesquisa em Solos. Sistema brasileiro de classificação de solos. Brasília: Embrapa - SPI; Rio de Janeiro: Embrapa Solos 2006. $306 p$.

Ferreira, D.F. Análises estatísticas por meio do SISVAR (Sistema para análise de variância) para Windows versão 4.0. In: reunião anual da região brasileira da sociedade internacional de biometria, 45. São Carlos, 2000. Anais. São Carlos, Universidade de São Carlos, 2000, 255-258.

G1 Rio Grande do Sul. Estiagem - Estiagem provoca queda de $43,8 \%$ na produção de soja no RS, diz Conab. 2012. Disponível em: <http://g1.globo.com/rs/ rio-grande-do-sul/estiagem/noticia/2012/06/estiagemprovoca-queda-de-438-na-producao-de-soja-no-rs-dizconab.html> Acesso em 4 jan 2018.

Gazolla-Neto, A. et al. Níveis de umidade do solo de várzea e seus efeitos sobre a emergência e crescimento inicial de plântulas de soja. Informativo ABRATES, 2012, 22, 2, 28-31.

Gomes, A. S. et al. Solos de várzea: uso e manejo. In.: Marcântonio, G. (coord.). Solos e irrigação. Porto Alegre: Ed. da UFRGS/DEDERACITE, 1992, 64-79.

Heatherly, L.G.; Pringle, H.C. Soybean Cultivars' Response to Flood Irrigation of Clay Soil. Agronomy Journal, 1991, 83, 231-236.

Marchezan E. et al. Sistemas de preparo do solo e rotação de culturas no controle de arroz vermelho em várzea. In.: Reunião da cultura do arroz irrigado, 21., Porto Alegre, RS. Anais...Porto Alegre: IRGA, 1995, 151-153.

Missio, E. L.; Rubin, S. A. L.; Gabe, N. L.; Ozelame, J. G. Desempenho de genótipos de soja em solo hidromórfico de várzea. Pesquisa Agropecuária Gaúcha, 2010, 16, 1 e 2, 23-29.

Moreno, J.A. Clima do Rio Grande do Sul. Porto Alegre, Secretaria de Agricultura, 1961. 73p.
Mota, F.S. Condições climáticas e produção de soja no sul do Brasil. In: Vernetti, F. de J. (Coord.) Soja. Campinas: Fundação Cargill, 1983. 463p.

Peron Ferrari S/A. BMX Turbo RR Brasmax. Disponível em: <http://www.peronferrari.com.br/produtos/graos/ soja/bmx-turbo-rr-brasmax-11.html>. Acesso em 03/01/2019.

Pires, J. L. F.; Soprano, E.; Cassol, B. Adaptações morfofisiológicas da soja em solo inundado. Pesquisa Agropecuária Brasileira, 2002, 37, 1, 41-50.

Reyna, N. et al. Evaluation of QTL for Waterlogging Tolerance Insouthern Soybean Germplasm. Crop Science, 2003, 43, 2077-2082.

Sediyama, T.; Silva, F.; Borém, A. Soja: do plantio à colheita. UFV $1^{a}$ Edição. 2015. 333p.

Sementes Roos. Brasmax Ativa RR. 2018. Disponível em: $\quad<h t t p: / / s e m e n t e s r o o s . c o m . b r / w p-c o n t e n t /$ uploads/2018/01/roos-folder-2018-ativa.png>. Acesso em 04 out 2018.

Serres, B. J.; Voesenek, L. A. C. J. Flooding Stress: Acclimations and Genetic Diversity. Annual Review of Plants Biology, 2008, 59, 313-39.

Sociedade Brasileira de Ciência do Solo - Núcleo Regional Sul. Manual de adubação e de calagem para os estados do RS e SC. 10 ed. Porto Alegre: Sociedade Brasileira de Ciência do Solo - Núcleo Regional Sul, 2004. 394p.

Taiz L.; Zeiger, R. Fisiologia Vegetal. 4. ed. Porto Alegre, Artmed, 848 p. 2009.

Vernetti Junior, F. J. et al. Arroz irrigado em sucessão a milho e soja. In: Congresso brasileiro de arroz irrigado, 3; Reunião da Cultura de Arroz Irrigado 25, 2003, Balneário Camboriú, SC. Anais... Itajaí: EPAGRI, 2003. p.246-247.

Vernetti Junior, F. J.; Gomes, A. S.; Schuch, L. O. B. Sustentabilidade de sistemas de rotação e sucessão de culturas em solos de várzea no Sul do Brasil. Ciência Rural, 2009, 39, 6, 1708-1714. 